\title{
The Development of a Reading Comprehension Test
}

\author{
Ezgi Çetinkaya Özdemir ${ }^{1, *}$, Hayati Akyol ${ }^{2}$ \\ ${ }^{1}$ Faculty of education, Kafkas University, Turkey \\ ${ }^{2}$ Faculty of education, Gazi University, Turkey
}

Copyright $\bigcirc 2019$ by authors, all rights reserved. Authors agree that this article remains permanently open access under the terms of the Creative Commons Attribution License 4.0 International License

\begin{abstract}
Reading comprehension has an important place in lifelong learning. It is an interactive process between the reader and the text. Students need reading comprehension skills at all educational levels and for all school subjects. Determining the level of students' reading comprehension skills is the subject of testing and evaluation. Tests used to measure students' success are expected to provide accurate and reliable information. Therefore, the aim of this study is to develop a valid and reliable reading comprehension test appropriate for fourth grade reading comprehension learning outcomes. The participants in the study were 245 fourth graders from three schools at low, middle and high socioeconomic levels in the central district of Kars. Items with discrimination indices below .30 and those that did not differ by $27 \%$ in the upper and lower groups on the independent groups t-test were excluded from the test. The difficulty indices of the test items ranged from .37 to .79 . The KR-20 reliability coefficient was found to be 0.83 , indicating that this multiple choice reading comprehension test is valid and reliable.
\end{abstract}

Keywords Reading Comprehension, Test Development, Validity and Reliability

\section{Introduction}

Reading, a required skill in academic and social life, is a basic language skill. Although there are many definitions of reading, Akyol's (2013) definition: "the process of establishing meaning in a suitable environment using appropriate information based on effective communication between the author and the reader in accordance with the appropriate aim and method," may be the most descriptive. As this definition indicates, reading and comprehension may seem to be different things, but are actually two parts of a whole that needs continuous improvement in education [15].

According to Oakley (2011), reading comprehension is the desired result of reading and can be defined as the skill of combining background knowledge with reading texts [25]. Reading comprehension has an important place in lifelong learning [10]. It is an interactive process between the reader and the text. Comprehension is affected by the experiences, abilities, motivation and reading goals of the reader [3]. Kintsch (2004) notes that it requires identifying and understanding the important ideas of texts and making inferences based on both texts and background knowledge.

Students need reading comprehension skills at all educational levels and for all school subjects [4]. Determining the level of students' reading comprehension skills is the subject of testing and evaluation [2]. The examinations in education and training show the extent to which desired behaviors and skills have been acquired. Huang and $\mathrm{Wu}$ (2013) assert that tests have become important recently due to their formative assessment roles in facilitating students' learning.

The most common assessment tools used by teachers are multiple choice tests. The results of a highly reliable and valid test can be generalized, large numbers of people can use them quickly at a low cost, and they are reusable [27].

According to Ogan Bekiroğlu (2004), studies show that tests, following interviews, are the most widely used instrument for revealing students' comprehension of a subject or concept.

Testing is an important way to measure learning outcomes. One of the functions of testing is to measure the success of education and training. Therefore, education, training and testing should not be imagined to be separate from each other [12]. However, it is important that tests should be reliable and valid. Most teachers prepare tests without considering test development standards. As a result, unreliable and invalid tests that fail to measure students' success consistently are frequently developed [12].

Tests used to measure the students' success should provide accurate and reliable information. The information obtained from test results enables the identification of learning activities and decisions about the precautions to be taken for the students at the same time [12]. Only these kinds of tests can seem as a good assessment tools.

There are a number of matters that need to be taken into 
consideration in test development. The most important are reliability and validity [22]. Reliability is the consistency between independent measurements of the same concept [16] or the degree to which measurement results are free from random errors [31]. Reliability is one of the first conditions of scientific research and determined by correlation coefficients (r) that vary between 0 and 1 . Reliability is considered to be high as the correlation coefficient approaches [16]. Validity is related to the degree to which the test measures the trait that is intended to be measured without mixing it with other personal traits [6]. According to Hughes (2003, p. 26), "a test is only valid if its aim is identified."

Many scientific studies of primary education are available in the literature of reading comprehension skills. However, most of them focus on understanding the relationship between reading comprehension and the variables that affect reading or determining the effect of various reading methods on reading comprehension skills rather than presenting a reading comprehension test or the process of test development. Çeliktürk Sezgin and Akyol (2018) conducted a study to understand the effect of a concept-based reading method on the reading motivation and comprehension of 26 primary school students in a Turkish course. Another study was intended to improve the reading comprehension skills of poor readers in fourth grade using different methods [21]. Yamaç and Çeliktürk Sezgin (2018) conducted a study with 128 fourth graders to determine the relationships between reading comprehension, reading anxiety, reading fluency and reading motivation. Sönmez and Sulak (2018) examined the effect of a think-aloud strategy on the reading comprehension skills in a study with 26 fourth graders. Another study of the relationship between a method and reading comprehension evaluated the usability of fill-in-the-blanks test in understanding the reading comprehension levels of fourth graders [19]. Kargin, Güldenoğlu and Ergül (2017) examined whether listening comprehension skills acquired in pre-school period predicted reading comprehension skill in grade 1. Another study examined the predictability of reading comprehension through fluent reading skills of students in grades 2, 3, 4 and 5 and the relationship between fluent reading and reading comprehension [5]. A study conducted with second graders investigated whether gender and age affected comprehension [8]. Ülker, Çetinkaya and Bayat (2016) developed a reliable and valid test for measuring the reading comprehension of secondary school students. Altunkaya (2016) developed the Turkish as a Foreign Language Reading Comprehension Test to measure the reading comprehension of students with $B$ level proficiency and showed that it was reliable and valid.

The aim of this study is to develop a valid and reliable reading comprehension test appropriate for fourth grade reading comprehension learning outcomes.

\section{Methodology}

\subsection{Research Design}

This study aimed to develop a valid and reliable achievement test appropriate for fourth grade reading comprehension learning acquisitions.

\subsection{Participants}

The participants in the study were 245 fourth grade students from three schools at low, middle and high socioeconomic levels in the central district of Kars.

Table 1. Descriptive Statistics for the Participants

\begin{tabular}{cccccc}
\hline School name & Number of students & Level & Female & Male & Socioeconomic level \\
\hline Kars Primary School & 52 & 4 & 28 & 24 & High \\
\hline $\begin{array}{c}\text { Gazi Ahmet Muhtar } \\
\text { Paşa Primary School }\end{array}$ & 111 & 4 & 48 & 63 & Middle \\
\hline $\begin{array}{c}\text { Namık Kemal Primary } \\
\text { School }\end{array}$ & 82 & 4 & 33 & 49 & Low \\
\hline
\end{tabular}




\subsection{Test Development}

The procedures proposed by Turgut and Baykul (2010, pp. 213-214) were used to develop the Reading Comprehension Test for Fourth Grade:

1. Identifying the test aims

2. Determining the traits to measure

3. Writing items

4. Item revision

5. Preparing the pilot test

6. Pilot test

7. Grading the pilot test results, item analysis and item selection

8. Creating the final test and statistics.

Based on these procedures, these operations were undertaken:

Identifying the test aims: The literature was reviewed with a focus on objectives, activities and reading texts for fourth graders.

Scanning the texts: The literature was reviewed to determine the texts for the test. Fourth grade Turkish textbooks approved by MNE's Board of Education, supplementary and child journals for fourth graders were examined and eight texts, four stories and four informative texts were selected.

Examining the Texts: In order to decide on the texts, they were sent to five experts (Appendix 1). Based on their opinions, one story and one informative text were chosen.

Composing Item Pools: A pool of 39 items was created based on the texts and the reading comprehension learning acquisitions.

Consulting Expert Opinions: In order to determine content validity, the items were sent to five experts
(Appendix 2). The experts were a full professor, two assistant professors and two Ph.D. students in the field of Turkish education. Two fourth graders were asked to read the texts to ensure their understandability. After consulting expert opinions, the test included 36 items.

Pilot test: The test template with multiple choice questions was administered to 245 fourth grade students.

\subsection{Data Analysis}

The results were divided into upper and lower groups by score. Difficulty and discrimination indices of the items on the test were calculated based on the responses of the upper and lower groups. Items with discrimination indices below .30 and those that did not differ by $27 \%$ in the upper and lower groups on the independent groups t-test were excluded from the test because they were found not to be discriminating. The difficulty indices of the test items ranged from .37 to .79. Items with an item total correlation of .30 or higher are good discriminators, those with values between .20 and .30 can be revised and kept on the test, and those with values lower than .20 should be excluded [7]. The items on this test were highly discriminating. The reliability of the achievement test, which included 22 items after the validity study, was examined using SPSS 22.0.

\section{Results}

The discrimination indices and difficulty levels of each item were calculated to determine their validity. The difficulty and discrimination values for each item on the 22-item achievement test are shown in Table 2.

Table 2. Reading Comprehension Test Item Analysis

\begin{tabular}{|c|c|c|c|c|c|}
\hline Item No & Groups & $\mathrm{Sj}$ & $\mathbf{P j}$ & rjx & $\mathbf{t}$ \\
\hline \multirow{2}{*}{ I 1} & $27 \%$ upper group & .24 & \multirow{2}{*}{.74} & \multirow{2}{*}{.36} & \multirow{2}{*}{$5.49 *$} \\
\hline & $27 \%$ lower group & .49 & & & \\
\hline \multirow{2}{*}{ I 2} & $27 \%$ upper group & .36 & \multirow{2}{*}{.75} & \multirow{2}{*}{.39} & \multirow{2}{*}{$5.29 *$} \\
\hline & $27 \%$ lower group & .50 & & & \\
\hline \multirow{2}{*}{ I 3} & $27 \%$ upper group & .37 & \multirow{2}{*}{.69} & \multirow{2}{*}{.57} & \multirow{2}{*}{$8.18^{*}$} \\
\hline & $27 \%$ lower group & .43 & & & \\
\hline \multirow[b]{2}{*}{ I 4} & $27 \%$ upper group & .17 & \multirow[b]{2}{*}{.68} & \multirow[b]{2}{*}{.57} & \multirow[b]{2}{*}{$9.13^{*}$} \\
\hline & $27 \%$ lower group & 49 & & & \\
\hline \multirow{2}{*}{ I 5} & $27 \%$ upper group & .00 & \multirow{2}{*}{.79} & \multirow{2}{*}{.54} & \multirow{2}{*}{$9.02 *$} \\
\hline & $27 \%$ lower group & .50 & & & \\
\hline \multirow{2}{*}{ I 6} & $27 \%$ upper group & .49 & \multirow{2}{*}{.59} & \multirow{2}{*}{.31} & \multirow{2}{*}{$3.92^{*}$} \\
\hline & $27 \%$ lower group & .45 & & & \\
\hline
\end{tabular}




\begin{tabular}{|c|c|c|c|c|c|}
\hline \multirow{2}{*}{ I 7} & $27 \%$ upper group & .46 & \multirow{2}{*}{.62} & \multirow{2}{*}{.39} & \multirow{2}{*}{$4.97 *$} \\
\hline & $27 \%$ lower group & .46 & & & \\
\hline \multirow{2}{*}{ I 8} & $27 \%$ upper group & .46 & \multirow{2}{*}{.53} & \multirow{2}{*}{.36} & \multirow{2}{*}{$4.54^{*}$} \\
\hline & $27 \%$ lower group & .47 & & & \\
\hline \multirow{2}{*}{ I 9} & $27 \%$ upper group & .31 & \multirow{2}{*}{.58} & \multirow{2}{*}{.54} & \multirow{2}{*}{$7.88^{*}$} \\
\hline & $27 \%$ lower group & .47 & & & \\
\hline \multirow{2}{*}{ I 10} & $27 \%$ upper group & .44 & \multirow{2}{*}{.46} & \multirow{2}{*}{.48} & \multirow{2}{*}{$6.41^{*}$} \\
\hline & $27 \%$ lower group & .43 & & & \\
\hline \multirow{2}{*}{ I 11} & $27 \%$ upper group & .40 & \multirow{2}{*}{.79} & \multirow{2}{*}{.30} & \multirow{2}{*}{$3.93 *$} \\
\hline & $27 \%$ lower group & .50 & & & \\
\hline \multirow{2}{*}{ I 12} & $27 \%$ upper group & .32 & \multirow{2}{*}{.79} & \multirow{2}{*}{.40} & \multirow{2}{*}{$5.66^{*}$} \\
\hline & $27 \%$ lower group & .50 & & & \\
\hline \multirow{2}{*}{ I 13} & $27 \%$ upper group & .28 & \multirow{2}{*}{.64} & \multirow{2}{*}{.48} & \multirow{2}{*}{$6.97^{*}$} \\
\hline & $27 \%$ lower group & .49 & & & \\
\hline \multirow[b]{2}{*}{ I 14} & $27 \%$ upper group & .37 & \multirow[b]{2}{*}{.74} & & \\
\hline & $27 \%$ lower group & .50 & & .34 & $4.62 *$ \\
\hline & $27 \%$ upper group & .17 & & & \\
\hline & $27 \%$ lower group & .48 & & & 0.70 \\
\hline & $27 \%$ upper group & .00 & & & \\
\hline . & $27 \%$ lower group & .47 & 17 & .00 & \\
\hline & $27 \%$ upper group & .48 & & & \\
\hline 117 & $27 \%$ lower group & .42 & .43 & .40 & $5.22^{*}$ \\
\hline & $27 \%$ upper group & .42 & & & \\
\hline 110 & $27 \%$ lower group & .43 & .44 &.$J 1$ & 0.35 \\
\hline & $27 \%$ upper group & .34 & & & \\
\hline 119 & $27 \%$ lower group & .46 & .64 & .54 & $1.12^{\pi}$ \\
\hline & $27 \%$ upper group & .26 & & & \\
\hline 120 & $27 \%$ lower group & .47 & .69 & .57 & $8.66^{*}$ \\
\hline & $27 \%$ upper group & .24 & & & \\
\hline I 21 & $27 \%$ lower group & .50 & .77 & .42 & $6.32 *$ \\
\hline & $27 \%$ upper group & .24 & & & \\
\hline I 22 & $27 \%$ lower group & .43 & .51 & .67 & $11.20^{*}$ \\
\hline
\end{tabular}


After item analysis, the KR-20 reliability coefficient was found to be 0.83 , which means that the test is reliable since reliability coefficients should be .70 or higher [7].

Table 3. Reading Comprehension Test Analysis Results

\begin{tabular}{cccccc}
\hline $\mathbf{N}$ & $\overline{\boldsymbol{X}}$ & SS & Median & Mode & KR-20 \\
\hline 245 & 14.42 & 4.80 & 15 & 18 & .83 \\
\hline
\end{tabular}

\section{Discussion}

Based on its theoretical framework, this study prepared 39 items for a reading comprehension test. This number then was reduced to 36 after consulting experts and the receiving feedback from the students about their understandability. The thirty-six-item reading comprehension test template was administered to 245 fourth graders. Analysis showed that the multiple choice reading comprehension test was reliable and valid. The final version of reading development test consisted of 22 multiple choice questions. The highest possible score on the test is 22, and the lowest is 0 .

Multiple choice tests have an important place in testing and evaluation. According to Tekin (2003, p. 149), answering multiple choice test requires special knowledge and ability takes less of students' time. Therefore, larger numbers of questions can be included on tests, which increases their validity and reliability. It is possible to differentiate between correct and incorrect answers on multiple choice tests. This makes grading accurate and objective. Factors other than the measured trait or traits should not influence the grading of students' performance. The consistency and difficulty of distractors also have an important role in items that test for misconceptions and careful thinking [12]. Temizkan and Sallabaş (2011) found that students were more successful with multiple choice reading comprehension questions than open-ended questions. On a multiple choice test about a text they read, $76.3 \%$ of the students correctly identified the topic, $73.1 \%$ identified the main idea, $74.2 \%$ identified the intention of the author, 69.9\% identified a cause-effect relationship, and $78.5 \%$ identified definitions in the text.

Studies of the measurement of reading comprehension skills have shown that multiple choice testing has an important place [35]; [36]; [17]; [26]; [37]. In this study, a multiple choice test was developed to measure the reading comprehension skills of fourth graders. Similar reading comprehension tests can be developed for students in other grades using other question types such as open-ended, true or false, fill-in-the-blanks and matching.

\section{Appendix}

\section{The Expert Opinion Form for the Selection of Texts on the Reading Comprehension Test}

Dear ......,

I am writing to ask you to help me with my research by evaluating these texts designed to test the reading comprehension skills of fourth graders. Considering the appropriateness of texts for the students' level, please tick the appropriate boxes in the table below. Thank you.

Sincerely,

Ezgi Çetinkaya Özdemir

\begin{tabular}{cc}
\hline Text Features & Not appropriate \\
\hline Students' level & Partially appropriate \\
\hline The topic of the text & appropriate \\
\hline The content of the text & \\
\hline The aim of the text & \\
\hline Cohesion & \\
\hline Main idea \\
\hline Supporting ideas \\
\hline Text length \\
\hline Heading-text relationship \\
\hline Wording \\
\hline Orthographic rules
\end{tabular}

Views and opinions: 


\section{The Expert Opinion Form for the Items on the Reading Comprehension Test}

Dear ......,

I am writing to ask you to help me with my Ph.D. research by providing your opinions about the items on a reading comprehension test that I am developing for fourth graders. Considering the characteristics of fourth graders, please indicate your evaluations in the table using the criteria indicated.

Sincerely,

Ezgi Çetinkaya Özdemir

0: The item is not appropriate, 1: The item should be revised, 2: The item is appropriate

\begin{tabular}{|c|c|c|c|c|}
\hline Items & $\begin{array}{l}\text { Appropriateness for the } \\
\text { students' level }\end{array}$ & $\begin{array}{l}\text { Appropriateness for the } \\
\text { rules of writing questions }\end{array}$ & $\begin{array}{c}\text { The relationship } \\
\text { between the text and } \\
\text { the question }\end{array}$ & $\begin{array}{l}\text { Appropriateness for the reading } \\
\text { comprehension learning } \\
\text { acquisitions }\end{array}$ \\
\hline I 1 & & & & \\
\hline I 2 & & & & \\
\hline I 3 & & & & \\
\hline I 4 & & & & \\
\hline I 5 & & & & \\
\hline I 6 & & & & \\
\hline I 7 & & & & \\
\hline I 8 & & & & \\
\hline I 9 & & & & \\
\hline I 10 & & & & \\
\hline I 11 & & & & \\
\hline I 12 & & & & \\
\hline I 13 & & & & \\
\hline I 14 & & & & \\
\hline I 15 & & & & \\
\hline I 16 & & & & \\
\hline I 17 & & & & \\
\hline I 18 & & & & \\
\hline I 19 & & & & \\
\hline I 20 & & & & \\
\hline I 21 & & & & \\
\hline I 22 & & & & \\
\hline I 23 & & & & \\
\hline
\end{tabular}




\begin{tabular}{|c|l|l|l|l|}
\hline I 24 & & & & \\
\hline I 25 & & & & \\
\hline I 26 & & & & \\
\hline I 27 & & & & \\
\hline I 28 & & & & \\
\hline I 29 & & & & \\
\hline I 30 & & & & \\
\hline I 31 & & & & \\
\hline I 32 & & & & \\
\hline I 33 & & & & \\
\hline I 34 & & & & \\
\hline I 35 & & & & \\
\hline I 36 & & & & \\
\hline
\end{tabular}

\section{Notes and suggestions:}

\section{REFERENCES}

[1] Akyol, H. (2013). Türkçe ilkokuma yazma öğretimi. (13. Bask1). Ankara: Pegem Akademi.

[2] Altunkaya, H. (2016). Yabancı Dil Olarak Türkçe Öğrenenlere Yönelik Okuduğunu Anlama Başarı Testinin Geliştirilmesi. TURKISH STUDIES-International Periodical for the Languages, Literature and History of Turkish or Turkic, 11(3), 113-138.

[3] Anastasiou, D. \& Griva, E. (2009). Awareness of reading strategy use and reading comprehension among poor and good readers. Elementary Education Online, 8, 283-297.

[4] Ateş, M. (2008). İlköğretim ikinci kademe öğrencilerinin okuduğunu anlama düzeyleri ile Türkçe dersine karşı tutumları ve akademik başarıları arasındaki ilişki. Yayımlanmamış Doktora Tezi, Selçuk Üniversitesi, Sosyal Bilimler Enstitüsü, Konya.

[5] Baştuğ M. \& Akyol, H. (2012). Akıcı okuma becerilerinin okuduğunu anlamayı yordama düzeyi. Kuramsal Ĕgitimbilim Dergisi, 5(4), 394-411.

[6] Büyüköztürk, Ş., Kılıç Çakmak, E., Akgün, Ö.E., Karadeniz, Ş. \& Demirel, F. (2014). Bilimsel araştırma yöntemleri.
Ankara: Pegem.

[7] Büyüköztürk, Ş. (2015). Veri analizi el kitabı. Pegem, Ankara.

[8] Ceran, E., Oğuzgiray Yıldız, M. \& Özdemir, İ. (2015). İlkokul 2. sınıf öğrencilerinin okuduğunu anlama becerilerinin cinsiyet ve yaşa göre incelenmesi. Sakarya University Journal of Education, 5(3), 151-166.

[9] Çeliktürk Sezgin, Z. \& Akyol, H . (2018). Kavram Odaklı Okuma Öğretiminin İlkokul Dördüncü Sınıf Öğrencilerinin Okuma Motivasyonuna ve Okuduklarını Anlamaya Etkisi. Ilköğretim Online, 546-561.

[10] Çiftçi, Ö. \& Temizyürek, F. (2008). İlköğretim 5. sınıf öğrencilerinin okuduğunu anlama becerilerinin ölçülmesi. Mustafa Kemal Üniversitesi Sosyal Bilimler Enstitüsü Dergisi, 5(9), 110-129.

[11] Gönen, S., Kocakaya, S. \& Kocakaya, F. (2011). Dinamik konusunda geçerliliği ve güvenilirliği sağlanmış bir başarı testi geliştirme çalışması. Yüzüncü Yll Üniversitesi, Eğitim Fakültesi Dergisi. VIII(I),40-57.

[12] Hanafi, A. (2016). Developing reading comprehension test for the first semester students of english department. Journal of English Language, Literature and Teaching.1(1), 57-74.

[13] Huang, T. W., \& Wu, P. C. (2013). Classroom-based cognitive diagnostic model for a teacher-made fraction- 
decimal test. Educational Technology \& Society, 16(3), 347-361.

[14] Hughes, A. (2003). Testing for Language Teachers. Cambridge: Cambridge University Press.

[15] Karatay, H. (2011). Okuma eğitimi kuram ve uygulama. Ankara: Berikan yayınevi.

[16] Karasar, N. (2012). Bilimsel Araştırma Yöntemi. Ankara: Nobel Yayınevi.

[17] Karasu, M. (2013). Diyaloğa dayalı ögretim stratejilerinin okuma tutum ve becerilerini geliştirmeye etkisi. Yayımlanmamış Doktora Tezi, Gazi Üniversitesi, Eğitim Bilimleri Enstitüsü, Ankara.

[18] Kargın, T., Güldenoğlu, B. \& Ergül, C. (2017). Dinlediğini anlama becerisinin okuduğunu anlama üzerindeki yordayıcılığının incelenmesi. Kastamonu Eğitim Dergisi, 25(6), 2369-2384.

[19] Kızılaslan Tunçer, B. \& Erden, G. (2015). Boşluk Doldurma Testlerinin İlkokul 4. Sınıf Öğrencilerinin Okuduğunu Anlama Düzeylerini Belirlemede Kullanılabilirliği. Bartın Üniversitesi Ĕgitim Fakültesi Dergisi, Özel sayı, 318-324.

[20] Kintsch, W. (2004). The construction-integration model of text comprehension and its implications for instruction. In R. B. Ruddell \& N. J. Unrau (Eds.), Theoretical models and processes of reading, (pp.1270-1328). Newark, DE: International Reading Association.

[21] Kodan, H. \& Akyol, H. (2018). Koro, Tekrarlı ve Yardımlı Okuma Yöntemlerinin Zayıf Okuyucuların Okuma ve Anlama Becerileri Üzerine Etkisi. Eğitim ve Bilim, 43(193), 159-179.

[22] Leary, M. R. (2008). Introduction to behavioural research methods. Boston, MA: Pearson Education.

[23] Oakley, G. (2011). The assessment of reading comprehension cognitive strategies: Practices and perceptions of Western Australian teachers. Australian Journal of Language and Literacy, 34, 279-292.

[24] Ogan Bekiroğlu, F. (2004). Ne kadar başarılı?, Klasik ve alternatif ölçme- değerlendirme yöntemleri ve fizikte uygulamalar. Ankara: Nobel Yayın Dağıtım.

[25] Onwuegbuzie, A.J., Mayes, E., Arthur, L., Johnson, J., Robinson, V., Ashe, S., Elbedour, S. \& Collins, K.M.T. (2004). Reading Comprehension Among African American Graduate Students. The Journal of Negro Education, 73 (4), 443- 457.
[26] Özdemir, Y. (2017). Okumadan önce, okuma esnasında, okumadan sonra düşün" stratejisinin okuduğunu anlama becerisine etkisi. Yayınlanmamıs Doktora Tezi, Ondokuz Mayıs Üniversitesi, Eğitim Bilimleri Enstitüsü, Samsun.

[27] Özgüven, İ. E. (2007). Psikolojik testler. Ankara: PDREM Yayınları.

[28] Sönmez, Y. \& Sulak, S.E. (2018). The Effect of the thinking-aloud strategy on the reading comprehension skills of 4th grade primary school students. Universal Journal of Educational Research 6(1), 168-172.

[29] Tekin, H. (2003). Eğitimde Ölçme ve Değerlendirme. Ankara: Yarg1 Yayınları.

[30] Temizkan, M. \& Sallabaş, M. (2011). Okuduğunu anlama becerisinin değerlendirilmesinde çoktan seçmeli testlerle açık uçlu yazılı yoklamaların karşılaştırılması. Dumlupınar Üniversitesi Sosyal Bilimleri Dergisi, 30, 207-220.

[31] Turgut M.F. (1995). Eğitimde Ölçme ve değerlendirme metodları. Ankara: Yargıcı Matbaası.

[32] Turgut, M. F. \& Baykul, Y. (2010). Eğitimde ölçme ve değerlendirme. Ankara: PegemA.

[33] Ülper, H., Çetinkaya, G. \& Bayat, N. (2016). Okuduğunu Anlama Testinin Geliștirilmesi. Ahi Evran Üniversitesi Kirşehir Eğitim Fakültesi Dergisi (KEFAD), 18(1), 175-187.

[34] Yamaç, A. \& Çeliktürk Sezgin, Z. (2018). İlkokul Dördünci் Sınıf Öğrencilerinin Okuma Kaygıları, Akıcılıkları, Motivasyonları ve Okuduğunu Anlamaları Arasındaki İlişkiler. Ĕgitim ve Bilim, 43(194), 225-243.

[35] Yıldırım, K. (2010). İşbirlikli ögrrenme yönteminin okumaya ilişkin bazı değişkenler üzerindeki etkisi ve yönteme ilişkin ögrenci- veli görüşleri. Yayımlanmamış Doktora Tezi, Gazi Üniversitesi, Eğitim Bilimleri Enstitüsü, Ankara.

[36] Yıldız, M. \& Akyol, H. (2011). İlköğretim 5. sınıf öğrencilerinin okuduğunu anlama, okuma motivasyonu ve okuma alışkanlıkları arasındaki ilişki. Gazi Eğitim Fakültesi Dergisi, 31(3), 793-815.

[37] Yıldız, M. \& Çetinkaya, E. (2017). The relationship between good readers' attention, reading fluency and reading comprehension. Universal Journal of Educational Research 5(3), 366-371. 